\title{
Intra-arterial blood pressure and cardiovascular responses in black and white hypertensives
}

\author{
DAVID B. Rowlands* \\ M.B., M.R.C.P. \\ ROBERT D. S. WATSON* \\ M.D., M.R.C.P.
}

\author{
Terence J. Stallard* \\ A.I.M.L.T. \\ William A. LitTLER* \\ M.D., F.R.C.P.
}

\author{
Joe DE Giovanni $\dagger$ \\ M.B., M.R.C.P. \\ *Department of Cardiovascular Medicine, East Birmingham Hospital and University \\ $\dagger$ The Children's Hospital, Birmingham
}

\begin{abstract}
Summary
Sixteen black hypertensive patients were matched for age, sex, casual blood pressure and socio-economic status with 16 white hypertensives. All patients underwent continuous intra-arterial ambulatory monitoring of blood pressure, assessment of baroreflex activity and pressor response to exercise and cold. No differences were observed in the blood pressure and cardiovascular responses between the group.
\end{abstract}

\section{Introduction}

The difference in hypertension between black and white patients is attracting increasing interest on both sides of the Atlantic. The morbidity and mortality are much higher in black hypertensives (Stamler et al., 1974) than in white although it would now seem that the prevalence is similar in both groups (U.S.A. Government National Health and Nutritional Survey Report, 1973). Work has shown that the kidney in the black hypertensive is more susceptible to nephrosclerosis than it is in whites (Levy et al., 1978), and it has been suggested that the increased incidence of hypertensive complications in blacks, particularly cerebrovascular, may be due to abnormal vasculature and vascular responses.

The purpose of this study was to examine blood pressure (BP) over an extended period in black and white hypertensives, to look at some aspects of BP control and to examine the cardiovascular response to stress tests.

\section{Patients and methods}

Sixteen blacks with mild-to-moderate hypertension were matched for age, sex, casual BP readings and socio-economic status with 16 white hypertensive patients (Table 1). No patients hadevidence of target organ damage and none was on hypotensive therapy.

All patients were studied as hospital in-patients? under standardized conditions, when they under-went a 24-hr period of continuous ambulato $\mathrm{y}_{-}$ intra-arterial monitoring of BP (Littler et al., 1972 ..$\infty$ Patients were supplied with a diary and asked $\bar{\Phi} 0$ record the time of retiring at night and early morningo waking, so that BP could be analysed for the totals 24-hr period, the awake period and during sleep.o During the study sensitivity of sino-aortic baro-年 reflexes was measured (Smyth, Sleight and Pickering, $\stackrel{\triangleright}{\varrho}$ 1969) and the BP and heart rate response to sub- $\overrightarrow{\vec{B}}$ maximal bicycle exercise and to cold were measured. 3

Results are expressed as the mean \pm s.d. and differences between the groups assessed by Student's? $t$-test.

\section{Results}

The mean 24-hr BP for the blacks of $128 / 82^{3}$. $\mathrm{mmHg}$ was not significantly different from that of the whites, $135 / 85 \mathrm{mmHg}$. Similarly the mean awake BP of both groups was not different, although음 the mean awake BP of blacks and whites were significantly lower than mean casual BP readings. For blacks the casual BP was $158 \pm 12 / 102 \pm 7 \mathrm{~N}$ $\mathrm{mmHg}$ compared with the awake BP of $134 \pm 15 \%$ $86 \pm 11 \mathrm{mmHg}(P<0.001)$. The figures for whites were $163 \pm 15 / 100 \pm 7 \mathrm{mmHg}$ (casual) and $140 \pm 14 / \omega$ $89 \pm 10 \mathrm{mmHg}$ (awake) $(P<0 \cdot 001)$.

The mean sleep BP was $113 \pm 16 / 17 \pm 11 \mathrm{mmHg} \circ$ in the blacks representing a mean percentage fall of $\Phi$ systolic and diastolic BP from the awake BP of $\stackrel{+}{+}$ $16 \%$ in both cases. In the whites, the mean sleep $\frac{0}{0}$ $\mathrm{BP}$ was $121 \pm 13 / 75 \pm 9 \mathrm{mmHg}$, the mean percentage $\frac{0}{\mathrm{D}}$ 
falls being $14 \%$ and $15 \%$ systolic and diastolic respectively.

The values of variability of awake systolic BP (blacks, $17 \pm 4 \mathrm{mmHg}$; whites, $17 \pm 3 \mathrm{mmHg}$ ) and awake diastolic BP (blacks, $13 \pm 3 \mathrm{mmHg}$; whites, $12 \pm 2 \mathrm{mmHg}$ ) were again not different.

Mean baroreflex activity in blacks was $8 \cdot 5 \pm 4 \cdot 5$ $\mathrm{msec} / \mathrm{mmHg}$, similar to that found in the whites of $7 \cdot 2 \pm 3 \mathrm{msec} / \mathrm{mmHg}$.

The mean changes in systolic BP and heart rate in response to the pressor stimuli of cold and exercise are shown in Table 1, and were again not statistically different.

TABLE 1. Age and BP comparisions of blacks and whites

\begin{tabular}{|c|c|c|}
\hline & $\begin{array}{l}\text { Blacks } \\
(9 \text { male, } \\
7 \text { female) }\end{array}$ & $\begin{array}{l}\text { Whites } \\
(9 \text { male, } \\
7 \text { female) }\end{array}$ \\
\hline Mean age (years) & $42 \pm 10$ & $43 \pm 10$ \\
\hline $\begin{array}{r}\text { Casual BP (mmHg)-systolic } \\
\text {-diastolic }\end{array}$ & $\begin{array}{l}158 \pm 12 \\
102 \pm 7\end{array}$ & $\begin{array}{l}163 \pm 15 \\
100 \pm 7\end{array}$ \\
\hline $\begin{array}{l}\text { Exercise } \\
\text { Mean change in systolic } \mathrm{BP}(\mathrm{mmHg}) \\
\text { Mean change in heart rate (beats/min) }\end{array}$ & $\begin{array}{l}72 \pm 29 \\
67 \pm 22\end{array}$ & $\begin{array}{l}62 \pm 22 \\
75 \pm 18\end{array}$ \\
\hline $\begin{array}{l}\text { Cold pressor } \\
\text { Mean change in systolic } \mathrm{BP}(\mathrm{mmHg}) \\
\text { Mean change in heart rate (beats } / \mathrm{min})\end{array}$ & $\begin{array}{r}28 \pm 16 \\
9 \pm 5\end{array}$ & $\begin{array}{r}25 \pm 19 \\
4 \pm 9\end{array}$ \\
\hline
\end{tabular}

\section{Conclusions}

These data would suggest that for matched populations of black and white hypertensives, blood pressure and its variability over prolonged periods shows similar features.

Control of BP by the sino-aortic baroreflexes in both groups is similar and the haemodynamic responses to the stress of exercise and cold is again comparable in both blacks and whites.

If black hypertensives were more susceptible to the effects of hypertension on peripheral blood vessels, differences in BP variability, baroreflex activity and response to pressor stimuli would be anticipated. After matching these 2 groups of patients the similarities in response lend no support to this hypothesis.

\section{References}

Levy, S.B., Talner, L.B., Coel, M.N., Holle, R. \& Stone, R.A. (1978) Renal vasculature in essential hypertension: racial differences. Annals of Internal Medicine, 88, 12.

Littler, W.A., Honour, A.J., Sleight, P. \& Stott, F.D. (1972) Continuous recording of direct arterial pressure and electrocardiogram in unrestricted man. British Medical Journal, 3, 76.

Smyth, H.S., Sleight, P. \& Pickering, T.G. (1969) Reflex regulation of arterial pressure during sleep in man: a quantitative method of assessing baroreflex sensitivity. Circulation Research, 24, 109.

Stamler, J., Schoenberger, J.A. SNekelle, R.B. \& Stamler, R. (1974) Hypertension-the problem and the challenge. In: Hypertension Handbook 1974, pp. 3-31. Merck, Sharp \& Dohme, West Point, Pennsylvania.

U.S.A. Government National Health and Nutritional SURVEY REPORT, 1973. 